\title{
Rancang Bangun Sistem Basis Data Penelitian Menggunakan Top Down Approach
}

\author{
Edi Mulyana ${ }^{1}$, Agung Wahana ${ }^{2}$ \\ ${ }^{1}$ Teknik Elektro UIN Sunan Gunung Djati Bandung \\ ${ }^{2}$ Teknik Informatika UIN Sunan Gunung Djati Bandung \\ 1,2Jl. A.H. Nasution No. 105 Bandung \\ e-mail: 1edim@uinsgd.ac.id, ${ }^{2}$ wahana.agung@gmail.com
}

\begin{abstract}
Abstrak - Lembaga Penelitian dan Pengadian Msyarakat (LP2M) merupakan lembaga yang mengelola peneltian dan pengabdian masyarakat mempunyai tujuan salah satunya adalah: terkelolanya penelitian dengan memperhatikan peningkatan mutu, perluasan diversifikasi pendekatan, dan penguatan signifikasi sosial hasil penelitian, pengelolaan data yang berhubungan dengan penelitian sangat penting dilakukan agar data-data yang ada dapat dimanfaatkan dengan baik untuk pengambilan keputusan. Penyimpanan data yang masih dilakukan dalam bentuk phisik (hard Copy) dapat menimbulkan permasalahan dalam pengelolaan data. Penyimpanan data dalam sistem basis data dapat membantu dalam pengelolaan datadata penelitian. Basis data perlu dirancang untuk menghasilkan basis data yang optimal sehingga dapat memenuhi kebutuhan informasi bagi para pembuat keputusan yang berhubungan dengan penelitian. Perancangan basis data menggunakan pendekatan Top Down adalah merancang basis data relasional dengan model grafis / diagram atau normalisasi. Fase-fase perancangan terdiri dari: pengumpulan data dan analisis; perancangan basis data secara konseptual; perancangan basis data secara logika; pemilihan sistem manajemen basis data; perancangan basis data secara phisik dan implementasi basis data.
\end{abstract}

Kata kunci: data penelitian LP2M, pendekatan top down, perancangan basisdata, fase-fase perancangan

\section{Pendahuluan}

Sistem basis data dewasa ini pada suatu organisasi menjadi sesuatu yang sangat dibutuhkan. Hal ini karena sistem basisdata muncul dengan tujuan untuk memudahkan pengguna dalam menyimpan dan menampilkan informasi dari basisdata. Menyimpan dan menampilkan informasi sekilas seperti biasa jika data yang disimpan kecil, dan akan menjadi luar biasa jika data yang tersimpan cukup besar.

LP2M UIN Sunan Gunung Djati sebagai salah satu unit di lingkungan UIN Sunan Gunung Djati Bandung yang salah satu fungsinya adalah mengelola penelitian selama ini data penelitian masih disimpan dalam bentuk dokumen penelitian dan dalam sebuah media penyimpanan digital seperti Compact Disk (CD), hal ini tidak memberikan manfaat yang besar bagi pengolahan datadata penelitian untuk dibuat menjadi informasi bahkan menjadi sebuah pengetahuan yang sangat bermanfaat. Proses penciptaan informasi akan mengalami kesulitan dan membutuhkan waktu yang relatif lama karena proses penyusunannya masih dilakukan dengan membuat rekap berdasarkan dokumen fisik tadi. Pengolahan data yang belum tersimpan dalam sebuah basis data cenderung lama dan tidak banyak informasi dan pengetahuan yang dapat diciptakan. Penyimpanan data dalam sebuah basis data disamping untuk mempermudah pengolahan dan pengelolaan juga dapat menciptakan beragam informasi dan lebih jauh lagi dapat menciptakan suatu pengetahuan berdasarkan informasi yang telah diolah.

TELKA, Vol.3, No.2, November 2017, pp. 152 167

ISSN (e): 2540-9123

ISSN (p): 2502-1982 
Tujuan yang ingin dicapai pada penelitian ini adalah membangun sistem basisdata penelitian menggunakan top-down approach yang diharapkan dapat memudahkan untuk menyimpan dan menampilkan data-data hasil penelitiandi lingkungan LP2M UIN Sunan Gunung Djati Bandung. Permasalahan yang ingin diatasi adalah bagaimana rancang bangun sistem basisdata penelitian menggunakan top-down approach yang diharapkan dapat memudahkan proses penyimpanan dan proses menampilkan data-data hasil penelitian di lingkungan LP2M UIN Sunan Gunung Djati Bandung. Perancangan basis data merupakan kegiatan memodelkan kondisi nyata permasalahan dalam suatu lembaga atau institusi ke dalam suatu bentuk model basis data. Perancangan basis data secara top down dilakukan dengan memodelkan secara menyuluh dari kondisi yang ada menggunakan pemodelan Entity Realionship (ER) kemudian diterjemahkan menjadi lebih rinci atau detail menggunakan model data relasional.

\section{Sistem Basis Data}

\subsection{Pengertian Basis data dan Sistem Basis data}

Basis data atau database adalah sekumpulan relasi data logika, dan deskripsi dari data yang dirancang untuk memenuhi kebutuhan informasi organisasi. Basis data memungkinkan tempat penyimpanan datayangbesar dan dapat digunakan secara bersamaan oleh banyak departemen dan pengguna. Database mewakili entitas, atribut, dan hubungan logis antara entitas. [1] Basis data terdiri dari kumpulan data yang terorganisir, relasi antar data, dan objektifnya. Objektif utama adalah kecepatan dan kemudahan berinteraksi dengan data yang dikelola atau diolah.[2] Selain itu terdapat pengertian bahwa basis data adalah sekumpulan data persisten yang digunakan oleh aplikasi sistem dari perusahaan. [ 3 ] Jadi, dapat disimpulkan bahwa basis data adalah kumpulan data yang mewakili berbagai macam entitas dan hubungannya yang dapat digunakan secara bersamaan oleh banyak pengguna dan dirancang untuk memenuhi kebutuhan informasi organisasi.

\section{Database Management System (DBMS)}

Database Management System (DBMS) adalah suatu sistem perangkat lunak yang memungkinkan pengguna untuk mendefinisikan, membuat, memelihara, dan menyediakan akses kontrol terhadap basisdata[ 1 ]. DBMS adalah perangkat lunak yang menangani semua akses ke basis data. [3]. Selain itu menurut Ramakrishnan (2003, p3) DBMS adalah perangkat lunak yang dirancang untuk membantu pemeliharaan dan penggunaan sekumpulan besar dari data yang diperlukan oleh sistem yang seiring dengan penggunaannya berkembang dengan pesat.

\section{Komponen DBMS}

DBMS mempunyai lima komponen penting yaitu [1]:

a. Perangkat Keras

Dalam menjalankan aplikasi dan DBMS diperlukan perangkat keras. Perangkat keras dapat berupa sebuah komputer pribadi, sebuah mainframe, dan jaringan komputer. Perangkat keras merupakan suatu unsur fisik dari komputer yang dapat dilihat dan di sentuh oleh manusia secara langsung untuk mendukung proses komputerisasi.Untukmenjalankan DBMSmemerlukan kecepatan memory dan kapasitas hard disk tertentu.

b. Perangkat lunak

Komponen perangkat lunak meliputi perangkat lunak DBMS dan program aplikasi beserta sistem operasi, termasuk perangkat lunak tentang jaringan apabila DBMS digunakan dalam jaringan. Menurut Fathansyah [2] ada tiga jenis perangkat lunak yang terlibat dalam pengelolaan dan pengolahan basis data, yaitu:

1) Sistem Operasi. Merupakan pengendali semua operasi didalam sebuah komputer atau jaringan, Sistem Operasi juga menyediakan layanan low level (berbahasa mesin) bagi perangkat lunak. Contoh-contoh Sistem Operasi yang biasadigunakan saat ini seperti MSWindows, Unix, Linux, dan sebagainya. 
2) Sistem Pengelola Basis Data (DBMS). DBMS juga merupakan perangkat lunak yang menentukan bagaimana basis data dikelola dan diorganisasi secara fisik dalam media penyimpan perangkat komputer.

3) Aplikasi Pengguna. Merupakan kelompok perangkat lunak yang bersentuhan langsung dengan pemakai basis data (end-user).

c. Data.

Data merupakan komponen terpenting dari DBMS, khususnya dari sudut pandang end user sebagai jembatan penghubung komponen mesin dengan komponen manusia. Struktur dari basis data disebut dengan skema. Menurut Potter(2003,p352), data adalah fakta-fakta mentah, yang tidak terorganisir untuk menyampaikan arti yang spesifik. Sedangkan menurut Hoffer (2002, p4), data adalah kumpulan fakta, hasil-hasil pengujian, grafik, gambar, dan video yang mempunyai arti dalam lingkungan pengguna.

d. Prosedur.

Instruksi dan aturan yang mengatur desain dan pengguna dari basis data.Pengguna dari sistem dan staff yang mengatur basisdata memerlukan prosedur dokumen tentang bagaimana menggunakan atau menjalankan sistem. Prosedur ini terdiri dari beberapa instruksi tentang bagaimana untuk :

1) Masuk ke dalam DBMS

2) Menggunakan fasilitas DBMS tertentu atau program aplikasi c) Memulai dan mengakhiri DBMS

3) Membuat backup database

4) Menangani kerusakan perangkat lunak atau perangkat keras

5) Mengubah struktur dari table, mengatur basis data di beberapa tempat penyimpanan, meningkatkan performa, atau menyimpan data di secondary storage seperti hard disk drive.

e. Manusia (Pengguna).

Komponen terakhir yaitu manusia yang terlibat dalam sistem tersebut. Komponen pengguna [1] terdiri dari :

1) Data Administrator (DA). Data Administrator bertanggung jawab atas manajemen sumber daya data termasuk perencanaan basis data, pengembangan dan standar pemeliharaannya, peraturan dan prosedur, dan perancangan basis data secara konseptual/logis.

2) Database Administrator (DBA). DBA bertanggung jawab atas realisasi fisik dari basis data termasuk perancangan basis data fisik dan implementasi, keamanan dan kontrol yang terintegrasi, perawatan sistem operasional, dan meyakinkan kinerja aplikasi yang memuaskan pengguna.

3) Application Developer. Application Developer bertanggungjawab atas basis data setelah diimplementasikan, program aplikasi yang menyediakan fungsionalitas yang diperlukan untuk end-users harus diimplementasikan.

4) End-Users. End-Users adalah client basisdata yang telah dirancang dan diimplementasikan, serta dipelihara agar dapat menyediakan kebutuhan-kebutuhan informasi mereka. End-Users dapat diklasifikasikan berdasarkan cara mereka menggunakan sistem, yaitu

5) Nä̈ve Users. Merupakan pengguna yang tidak mengetahui sama sekali mengenai DBMS.

6) Sophisticated Users. Merupakan pengguna yang sudah mengenal struktur DBMS dengan baik dan mengetahui fasilitas-fasilitas yang ditawarkan oleh DBMS.

\subsection{Perancangan Basis Data (Database Design)}

Menurut Connolly dan Begg [1], perancangan basis data (database design) merupakan proses pembuatan suatu desain untuk sebuah basis data yang akan mendukung operasional dan tujuan suatu perusahaan. Ada dua pendekatan untuk mendesain sebuah basis data, yaitu :

a. Pendekatan bottom-up, dimulai pada tingkat awal dari atribut (properti dari entitas dan relationship), melalui analisis dari asosiasi antar atribut, dikelompokkan menjadi hubungan 
yang merepresentasikan jenis-jenis entitas dan hubungan antar entitas. Pendekatan ini cocok untuk mendesain basis data yang sederhana dengan jumlah atribut yang tidak banyak.

b. Pendekatan top-down, digunakan pada basis data yang lebih kompleks. Dimulai dengan pengembangan dari model data yang mengandung beberapa entitas dan hubungan tingkat tinggi, kemudian menggunakan perbaikan top-down berturut-turut untuk mengindentifikasikan entitas, hubungan dan atribut berkaitan tingkat rendah. Pendekatan ini biasanya digambarkan melalui Entity Relationship (ER)

Menurut Connolly dan Begg [1], perancangan basis data (database design) dibagi dalam tiga tahapan, yaitu :

a. Perancangan Konseptual (Conceptual Database Design)

Proses membangun suatu model berdasarkan informasi yang digunakan oleh perusahaan, tanpa pertimbangan perencanaan fisik. Model data dibangun dengan menggunakan informasi dalam spesifikasi kebutuhan pengguna.Model data konseptual merupakan sumber informasi untuk tahap desain logikal.

b. Perancangan Logikal (Logical Database Design)

Proses pembuatan suatu model informasi yang digunakan perusahaan berdasarkan pada model data yang spesifik, tetapi tidak tergantung dari DatabaseManagementSystem (DBMS) yang khusus dan pertimbangan fisik yang lain. Model data konseptual yang telah dibuat sebelumnya, diperbaiki dan dipetakan ke dalam model data logikal.

c. Perancangan Fisikal (Physical database design)

Proses untuk menghasilkan gambaran dari implementasi basis data pada tempat penyimpanan, menjelaskan dasar dari relasi, organisasi file, dan indeks yang digunakan untuk efisiensi data dan menghubungkan beberapa integrity constraints dan pengukuran keamanan.

Pemilihan DBMS (DBMS Selection)

Menurut Connollydan Begg [1], pemilihan DBMS yang sesuai untuk mendukung aplikasi basis data mencakup :

a. Mendefinisikan syarat-syarat referensi studi.

Menentukan tujuan, batasan masalah dan tugas yang harus dilakukan.

b. Mendaftar dua atau tiga jenis produk.

Membuat daftar barang-barang, misalnya darimana barang didapat, berapa biayanya, serta bagaimana bila ingin mendapatkannya.

c. Mengevaluasikan produk.

Barang-barang yang ada dalam barang diteliti lebih lanjut untuk mengetahui kelebihan dan kekurangan barang tersebut.

d. Merekomendasikan pilihan dan membuat laporan.

Langkah terakhir dari DBMS, yaitu mendokumentasikan proses dan untuk menyediakan pernyataan mengenai kesimpulan dan rekomendasi terhadap salah satu produk DBMS.

\subsection{Implementasi basidata (Implementation)}

Menurut Connolly dan Begg [1], implementasi merupakan realisasi fisik dari basis data dan desain aplikasi. Dalam tahap penyelesaian desain, kita dapat menerapkan basis data dan program aplikasi yang telah kita buat. Implementasi basis data menggunakan DDL yang kita pilih dalam melakukan pemilihan DBMS atau dengan menggunakan graphical user interface (GUI), yang menyediakan fungsional yang sama dengan pernyataan DDL yanglow level. Pandangan pengguna lainnya juga diimplementasikan. Data Manipulation Language (DML) digunakan untuk mengimplementasikan transaksi basis data di dalambagian aplikasi program dari tujuan DBMS. 


\section{Structure Query Language (SQL)}

SQL bukan hanya bahasa query, SQL berisi fitur dari Data Definition Language dan Data Manipulation Language (Atzeni, 2003, p85). Bahasa yang digunakan dalam basis data sebaiknya harus mengijinkan pengguna untuk membuat basis data dan struktur relasi. Serta dapat menampilkan tugas manajemen basisdata (memasukan, memperbaharui, penghapusandata), menyediakan pengubahan data, penghapusan data dan menyediakanquery yang sederhana maupun kompleks. SQL adalah salah satu contoh dari bahasa yang dirancang untuk menggunakan relasidalam mengubah input menjadi outputyang diinginkan.

\section{Data Definition Language}

Menurut Connolly dan Begg [1], data definition language (DDL) adalah sebuah bahasa yang mengijinkan DBA atau user untuk mendeskripsikan dan memberi nama entitas, atribut, dan hubungan yang diperlukan aplikasi beserta integrity yang berhubungan dan batasan keamanan.

Perintah-perintah data definition language (DDL) yang digunakan diantaranya:

a. Create Table, digunakan untuk membuat tabel dengan mengidentifikasi tipe data untuk setiap kolom.

b. Alter Table, digunakan untuk menambah atau membuang kolom dari konstrain.

c. Drop Table, digunakan untuk membuang atau menghapus table berserta semua data yang terkait didalamnya.

d. Create Index, digunakan untuk membuat indeks pada suatu tabel.

e. Drop Index, digunakan untuk membuang atau menghapus indeks yang telah dibuat sebelumnya

\section{Data Manipulation Language}

Menurut Connolly dan Begg [1], data manipulation language (DML) adalah sebuah bahasa yang menyediakan sekumpulan operasi yang mendukung suatu operasi manipulasi data yang berada dalam basis data. Pengoperasian data yang akan dimanipulasi pada umumnya meliputi :

a. Penambahan data baru ke dalam basis data.

b. Modifikasi data yang disimpan dalam basis data.

c. Pengembalian data yang terdapat dalam basis data.

d. Penghapusan data dari basis data.

Perintah-perintah yang ada pada data manipulation language (DML) diantaranya :

a. Select, digunakan untuk menampilkan sebagian atau seluruh isi dari suatu tabel dan menampilkan kombinasi isi dari beberapa tabel.

b. Update, digunakan untuk mengubah isi satu atau beberapa atribut dari suatu tabel.

c. Insert, digunakan untuk menambah satu atau beberapa baris nilai baru ke dalam suatu tabel.

d. Delete, digunakan untuk menghapus sebagian atau seluruh isi dari suatu tabel.

DML dikategorikan menjadi dua , yaitu :

a. Procedural DML. Sebuah bahasa yang memungkinkan pengguna untuk memberitahukan sistem data apa yang dibutuhkan dan bagaimana untuk mengambil data.

b. Non-Procedural DML. Sebuah bahasa yang memungkinkan pengguna untuk menyatakan data apa yang diperlukan daripada bagaimana harus diambil.

\section{Analisis Dan Perancangan}

Analisis bertujuan untuk menemukan permasalahan yang dihadapi oleh sebuah sistem untuk dicari rekomendasi penyelesaian kemudian dibangun rancangan sistemnya.

\subsection{Analsis sistem yang sedang berjalan}

LP2M telah memanfaatkan sistem informasi dalam mendukung aktivitasnya, tetapi belum semua aktivitas telah didukung oleh sistem informasi. Oleh karena itu perlu dilakukan inventarisasi terhadap data yang ada dalam lingkungan organisasi ini. Sistem yang berjalan saat ini berada pada sub domain dari website UIN Sunan Gunung Djati Bandung dengan url 
lp2m.uinsgd.ac.id merupakan sistem yang dibangun dan dikembangkan untuk menangani dan membantu aktivitas penelitian dan pengabdian kepada masyarakat. Sistem yang dipakai saat ini menangani data-data yang berhubungan dengan :
a. pendaftaran penelitian,
b. kontrak penelitian,
c. dokumen penelitian
d. jadwal penelitian
e. periode penelitian
f. jadwal presentasi
g. pegawai
h. gedung
i. ruangan
j. fakultas / bagian
k. jurusan / program studi
1. bidang ilmu
m. reviewer
n. Kategori penelitian

\subsection{Perancangan Basisdata}

Perancangan basisdata penelitian $1 \mathrm{p} 2 \mathrm{~m}$ melalui 3 (tiga) tahapan perancangan yang dilakukan, yaitu perancangan basisdata secara konseptual, perancangan basisdata secara fisik, dan pemilihan sistem basisdata.

\section{Perancangan Basisdata secara Konseptual}

Rancangan basisdata secara konseptual dijelaskan melalui gambar 1 berikut

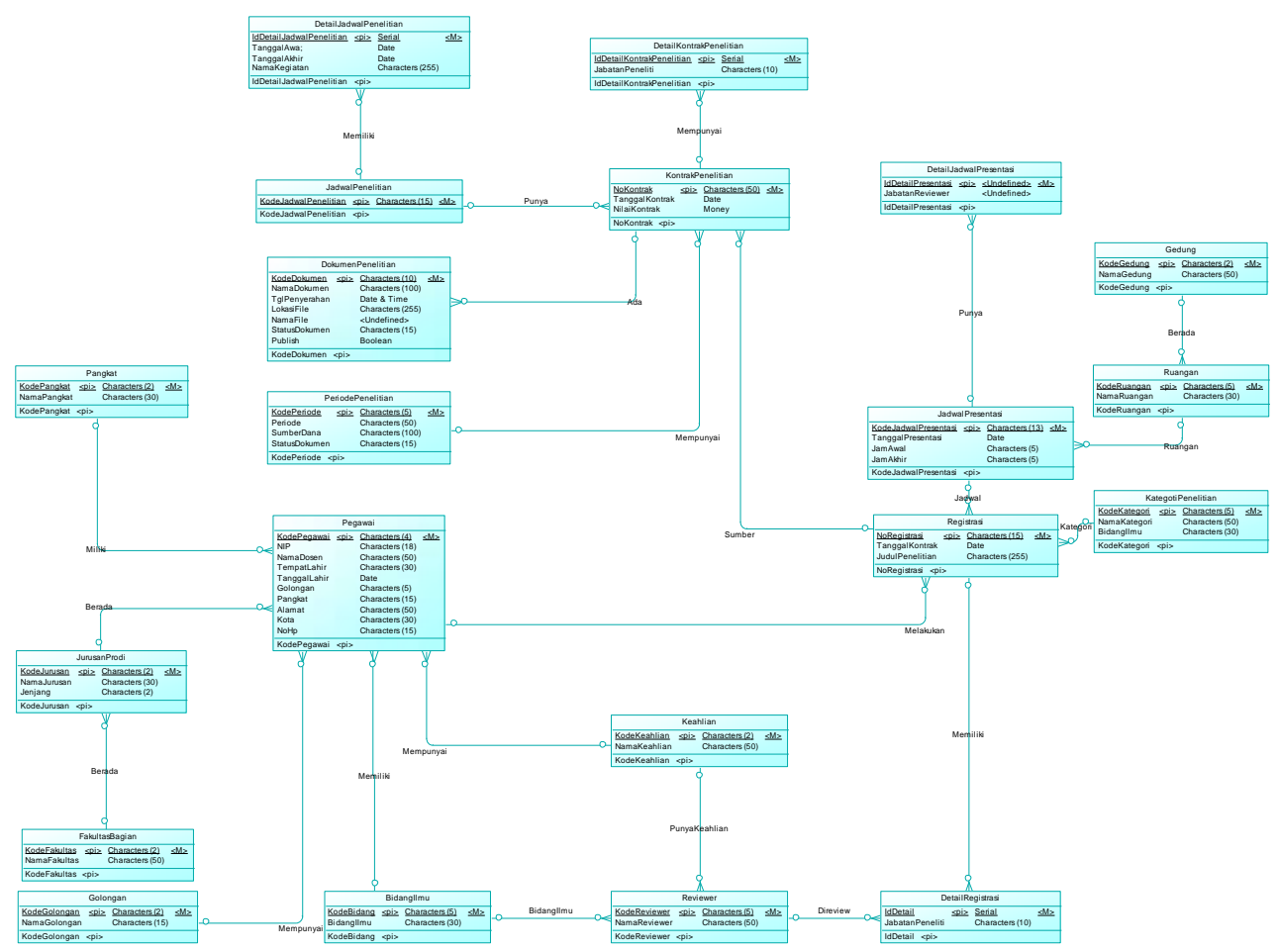

Gambar 1. Perancangan Basis Data Konseptual 


\section{Perancangan basis data secara fisik}

Basi sdata hasil perancangansecara konseptual kemudian ditransformasikan ke bentuk fisik menghasilkan rancangan basisdata secara fisik seperti pada gambar 2 berikut.

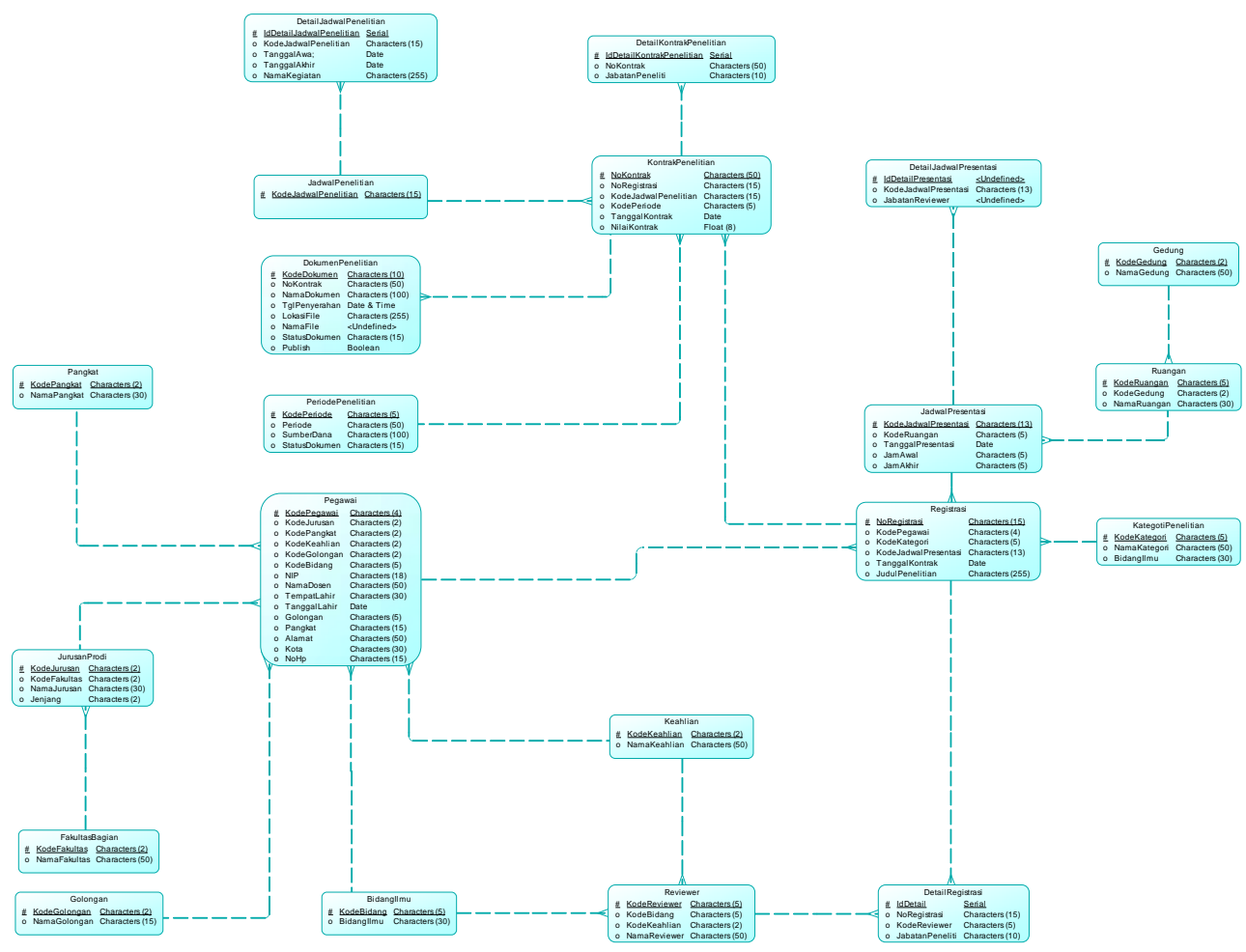

Gambar 2. Perancangan Basis data secara logik

\section{Pemilihan Sistem Manajemen Basisdata}

Sistem manajemen basis data yang digunakan dalam implementasi rancangan logik adalah MySQL Database server dengan pertimbangan :

a. Merupakan basis data yang bersifat open source.

b. Dukungan dari para komunitas dalam pengembangannya.

c. Homoginitas platform basis data yang digunakan di lingkungan UIN SGD.

\section{Implementasi}

Implementasi di sini merupakan perwujudan atau realisasi basisdata dalam bentuk pemrograman. Bahasa pemrograman untuk basisdata yang digunakan adalah Structure Query Language (SQL).

\subsection{Implementasi Basisdata}

Implementasi basisdata merupakan proses pembuatan basisdata $1 \mathrm{p} 2 \mathrm{~m}$. Instruksi untuk pembuatan basisdata $1 \mathrm{p} 2 \mathrm{~m}$ adalah sebagai berikut.

Create Database lp2m;

Use Database lp2m;

\subsection{Implementasi Tabel}

Implementasi tabel merupakan proses pembuatan tabel-tabel dalam basisdata $1 \mathrm{p} 2 \mathrm{~m}$. Instruksi untuk pembuatan tabel-tabel basisdata $1 \mathrm{p} 2 \mathrm{~m}$ adalah sebagai berikut. 


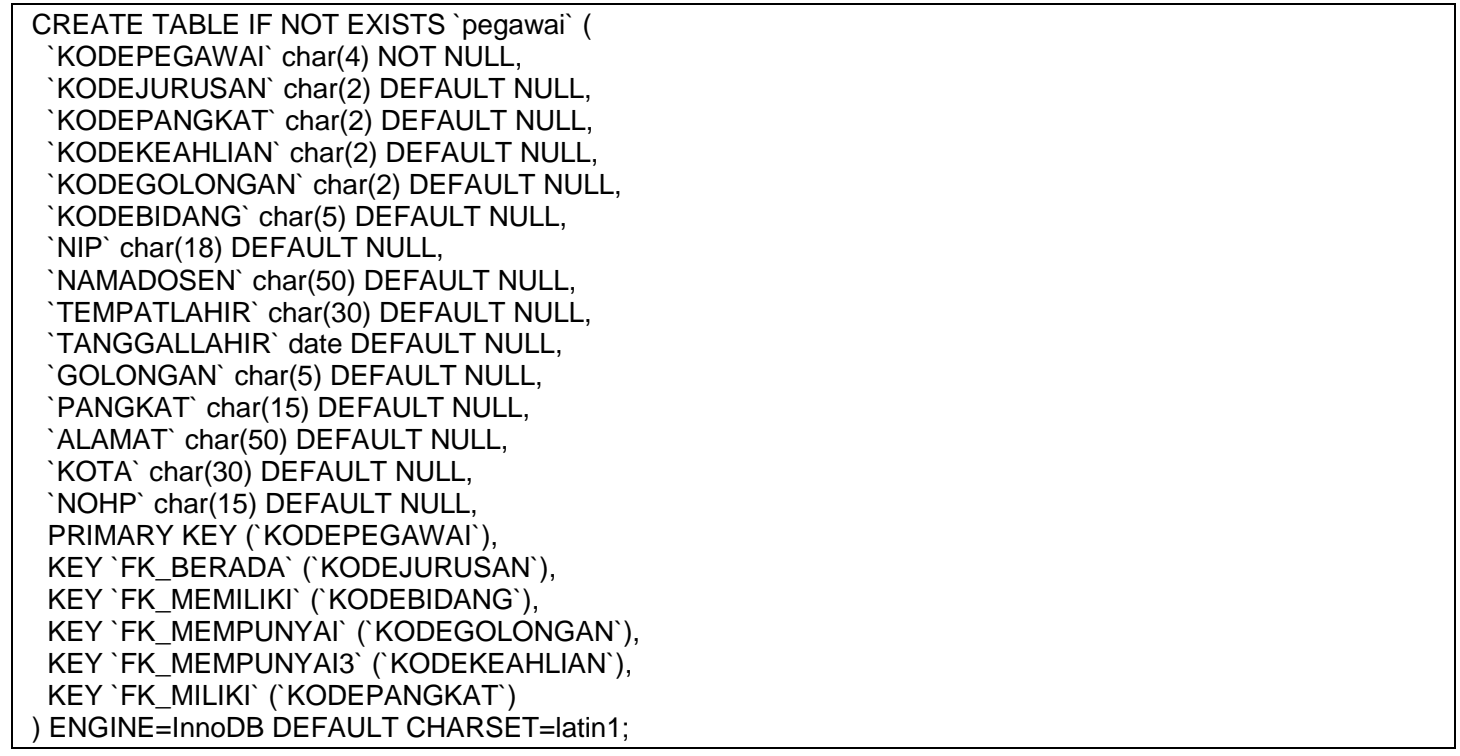

Gambar 3. Script Pembuatan Tabel Pegawai

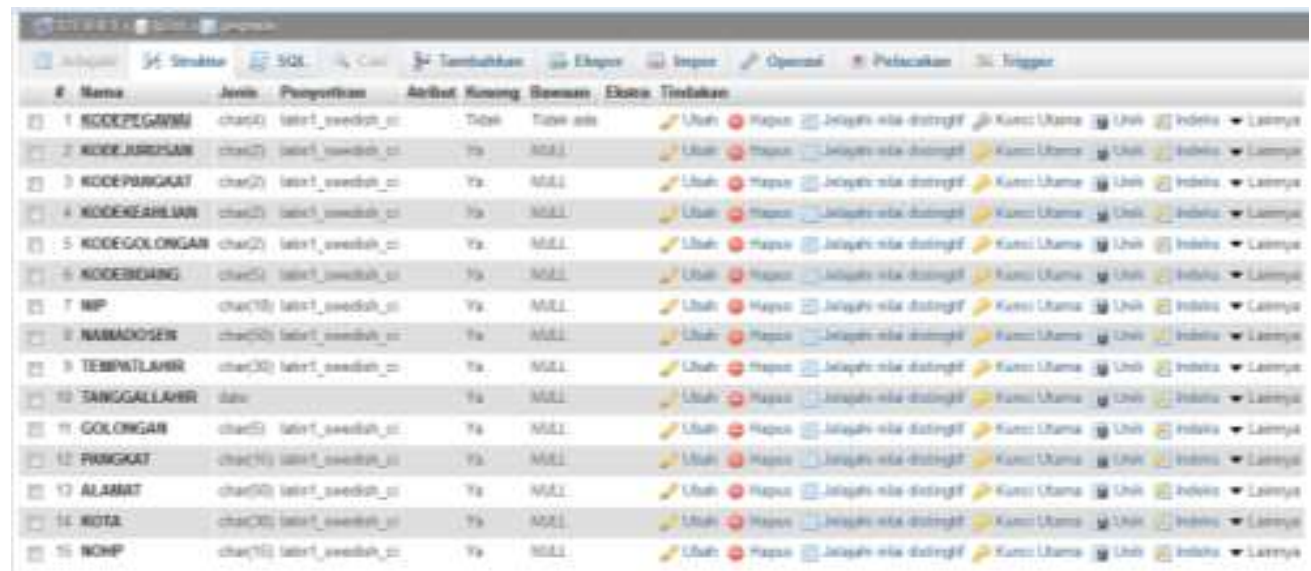

Gambar 4. Tabel Pegawai

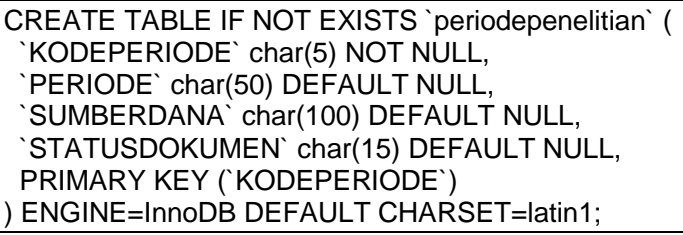

Gambar 5. Script Pembuatan Tabel Periode Penelitian

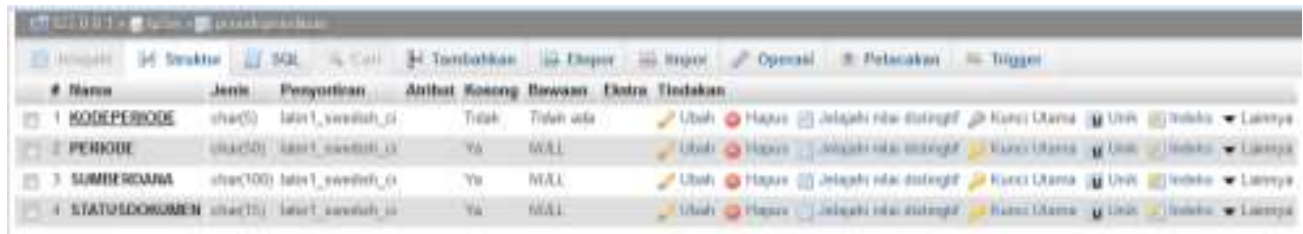

Gambar 6. Tabel Periode Penelitian 


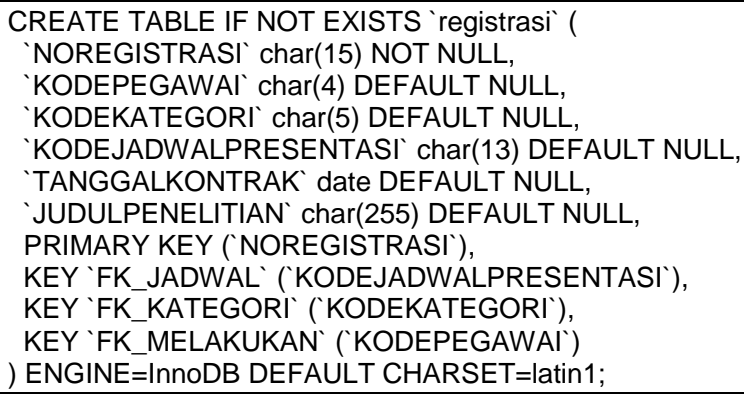

Gambar 7. Script Pembuatan Tabel Registrasi

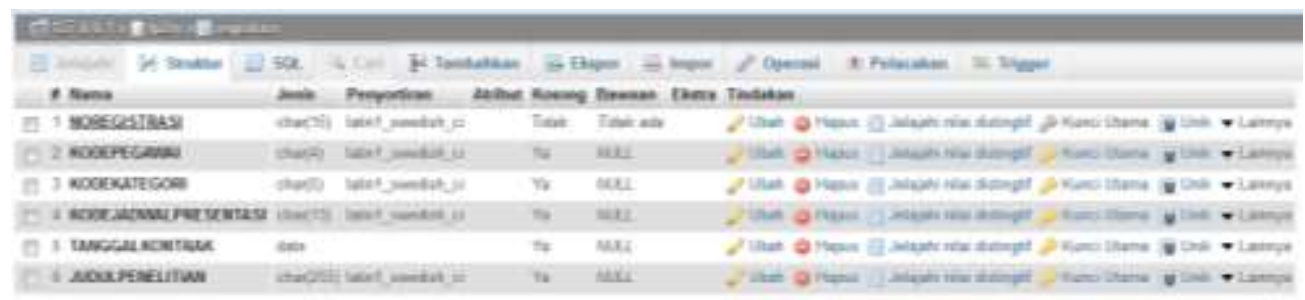

Gambar 8. Implementasi tabel Registrasi

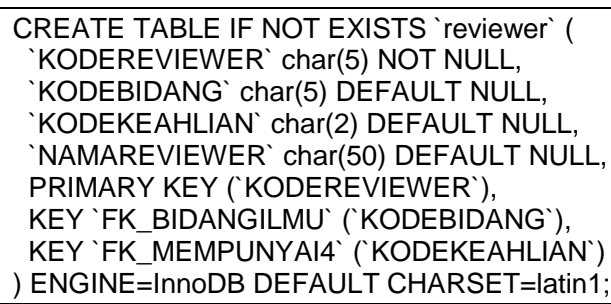

Gambar 9. Script Pembuatan Tabel Reviewer

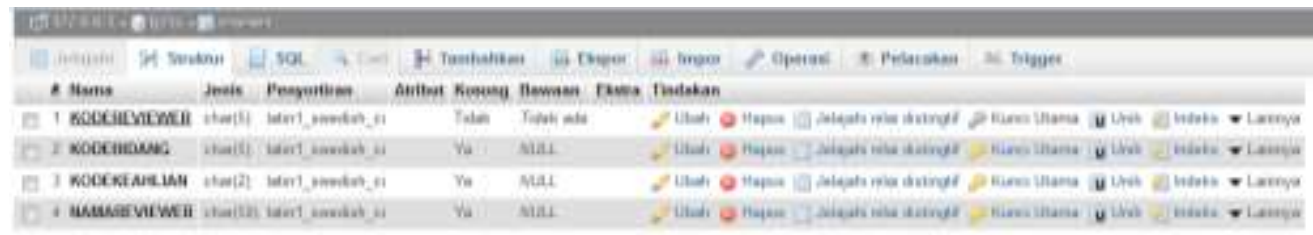

Gambar 10. Implementasi tabel Reviewer

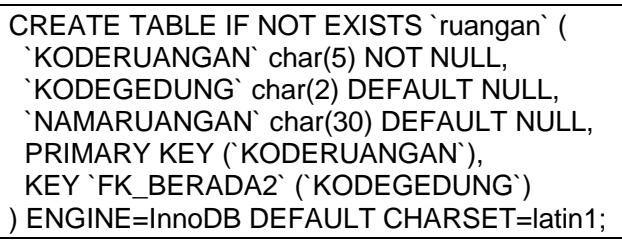

Gambar 11. Script Pembuatan Tabel Ruangan

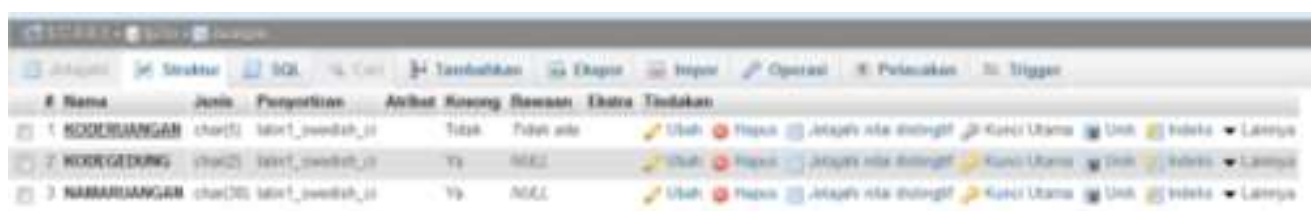

Gambar 12. Implementasi tabel Ruangan 


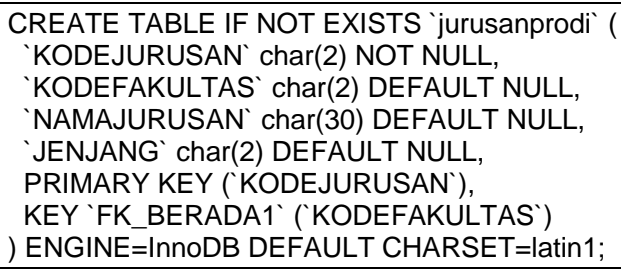

Gambar 13. Script Pembuatan Tabel Jurusan atau Prodi

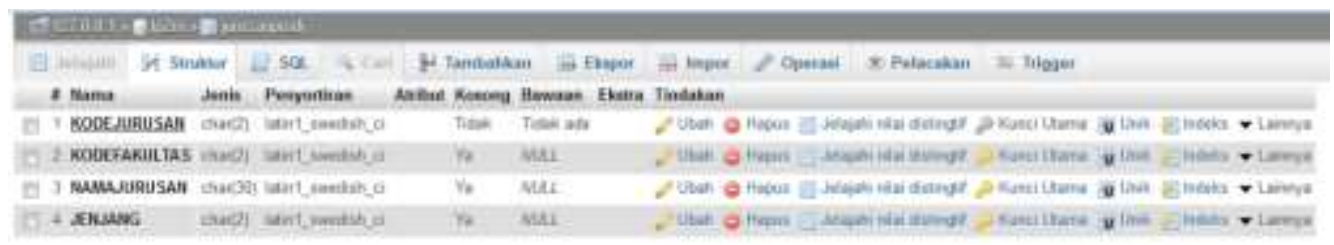

Gambar 14. Implementasi tabel Jurusan atau Prodi

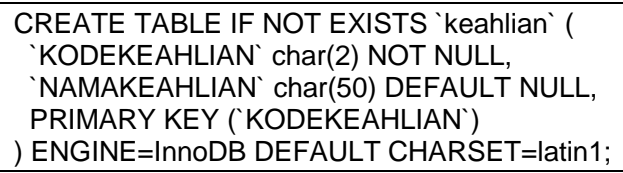

Gambar 15. Script Pembuatan Tabel Keahlian

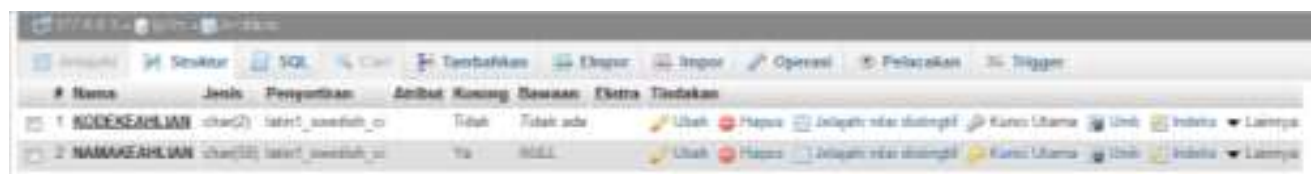

Gambar 16. Implementasi tabel Keahlian

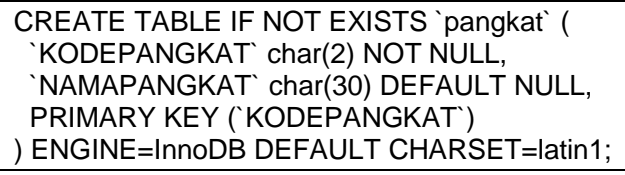

Gambar 17. Script Pembuatan Tabel Pangkat

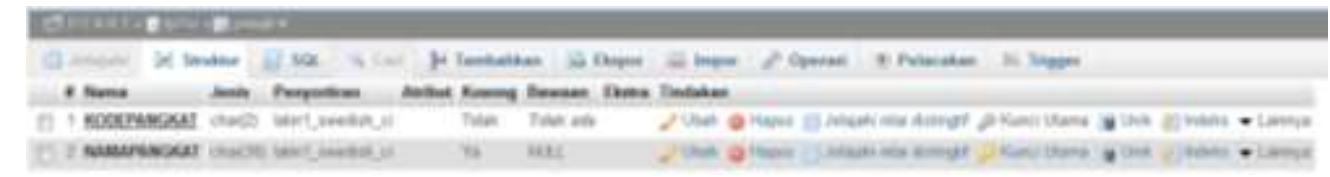

Gambar 18. Pangkat

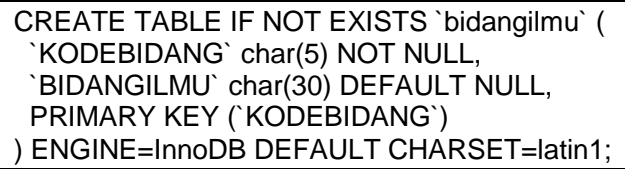

Gambar 19. Script Pembuatan Tabel Bidang Ilmu

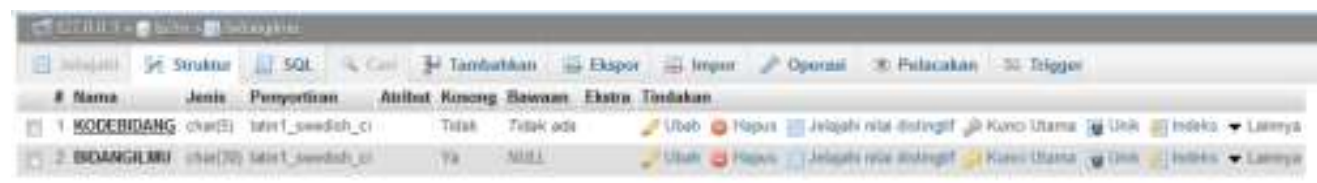

Gambar 20. Implementasi tabel Bidang Ilmu 


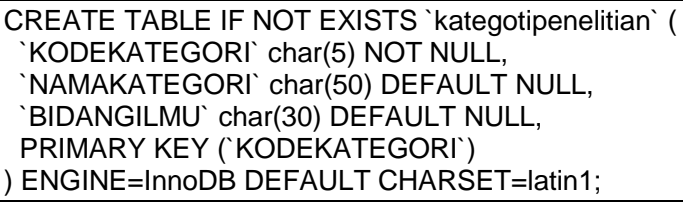

Gambar 21. Script Pembuatan Tabel Penelitian

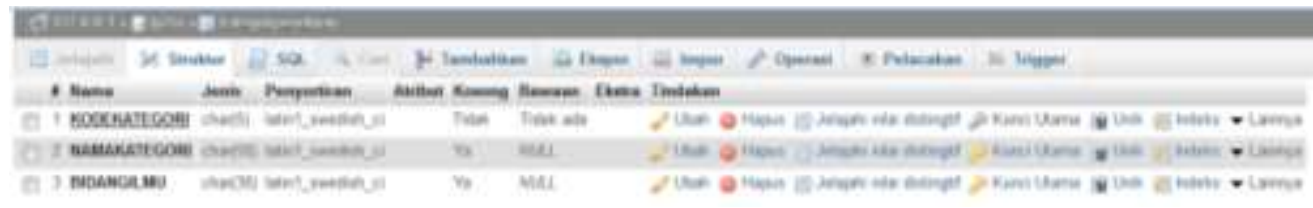

Gambar 22. Implementasi tabel Kategori Penelitian

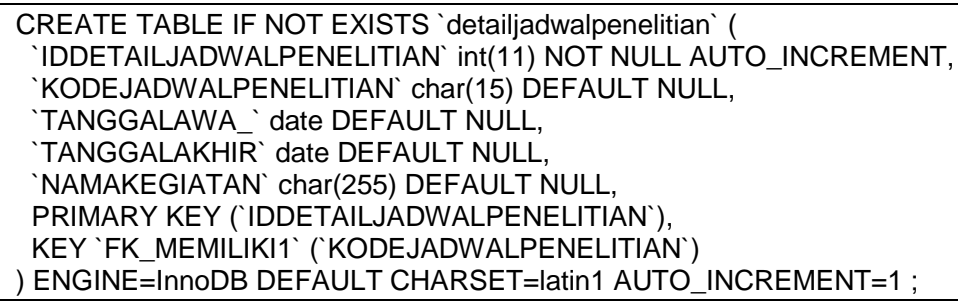

Gambar 22. Script Pembuatan Tabel Detail Jadwal Penelitian

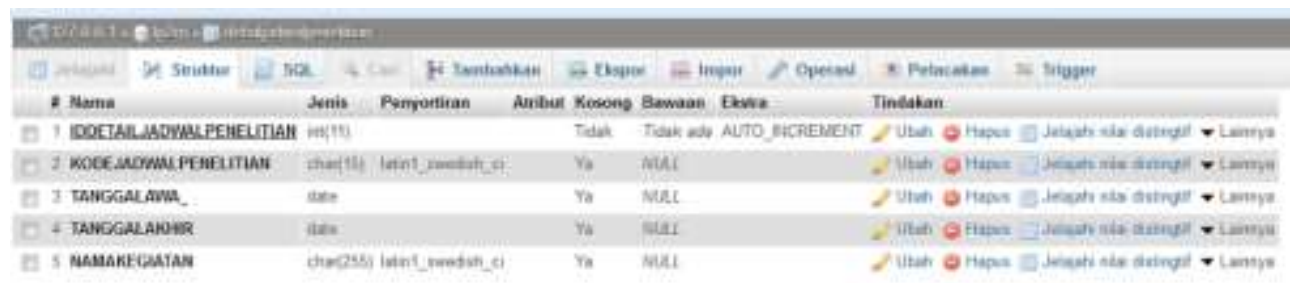

Gambar 24. Implementasi tabel Detail Jadwal Penelitian

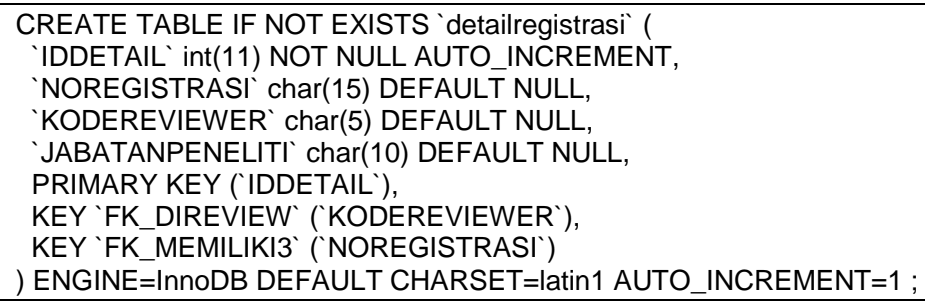

Gambar 25. Script Pembuatan Tabel Detail Presentasi

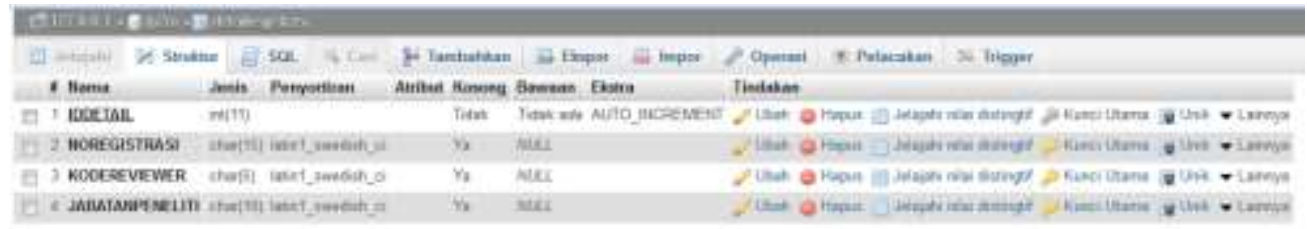

Gambar 26. Implementasi tabel Detail Presentasi

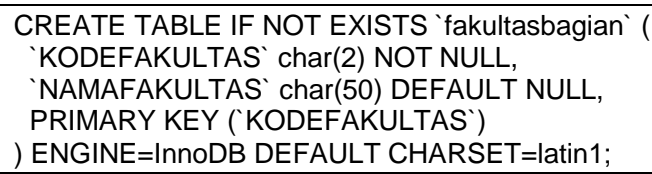

Gambar 27. Script Pembuatan Tabel Fakultas atau Bagian 


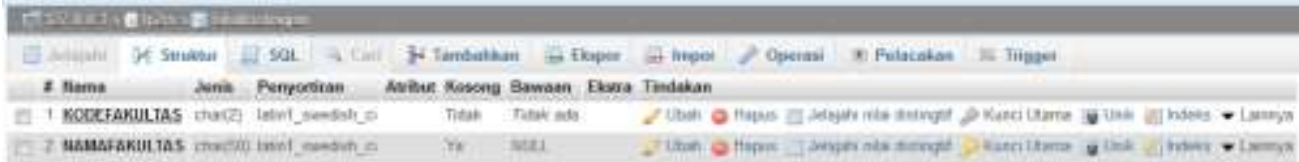

Gambar 28. Implementasi tabel Fakultas atau Bagian

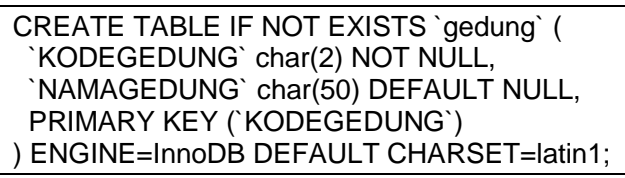

Gambar 29. Script Pembuatan Tabel Gedung

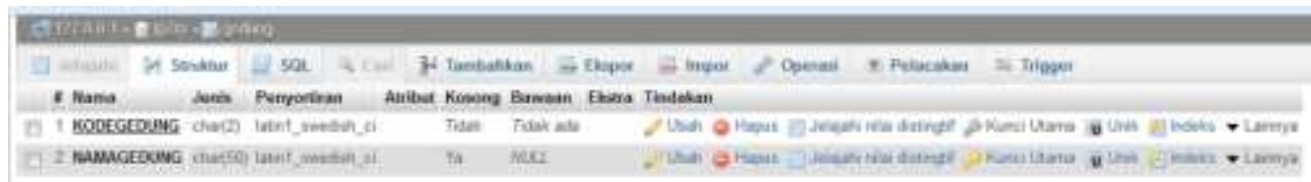

Gambar 30. Implementasi tabel Gedung

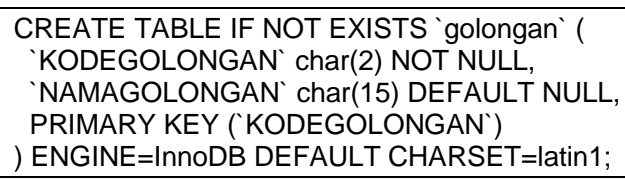

Gambar 31. Script Pembuatan Tabel Golongan

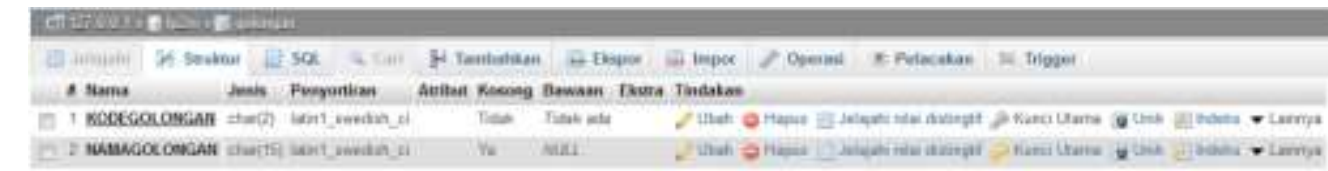

Gambar 32. Implementasi tabel Golongan

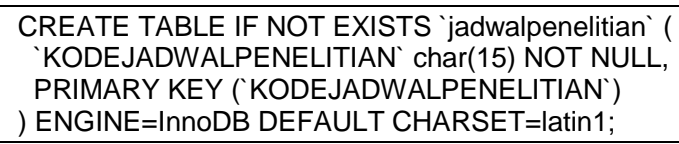

Gambar 33. Script Pembuatan Tabel Jadwan Penelitian

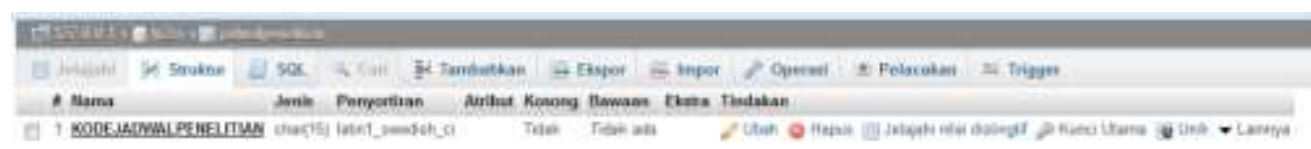

Gambar 34. Implementasi tabel JadwalPenelitian

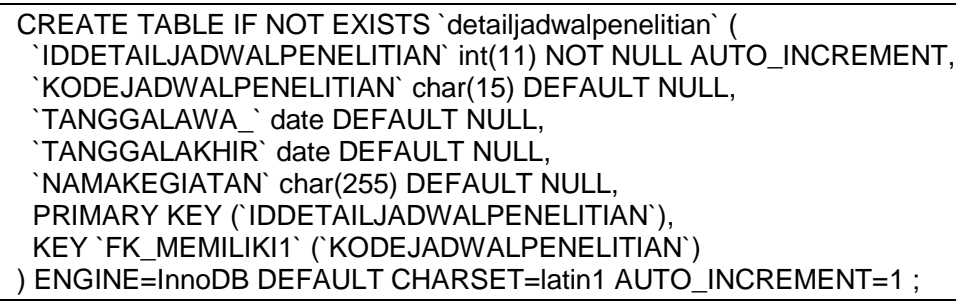

Gambar 35. Script Pembuatan Tabel Detail Jadwan Penelitian 


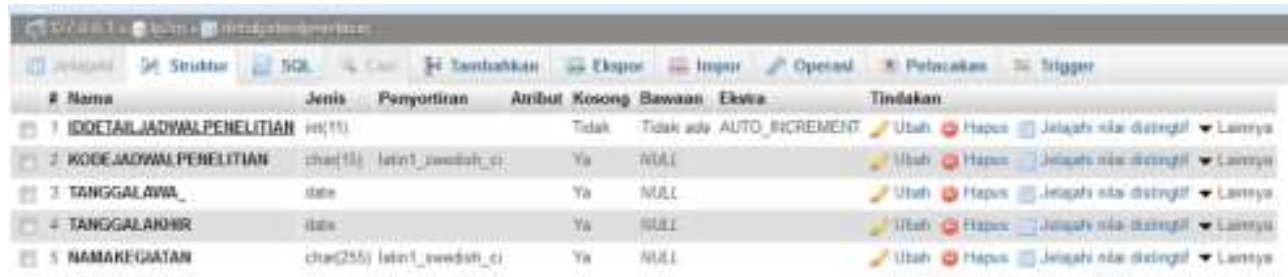

Gambar 36. Implementasi tabel Detail Jadwal Penelitian

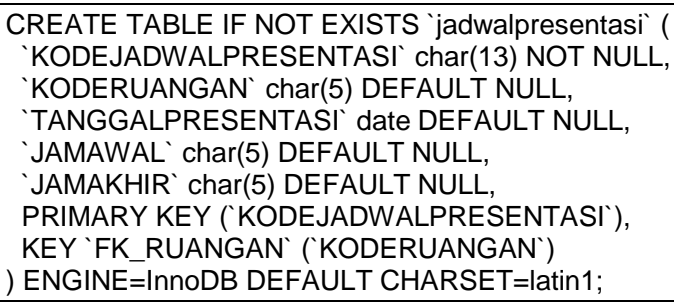

Gambar 37. Script Pembuatan Tabel Presentasi

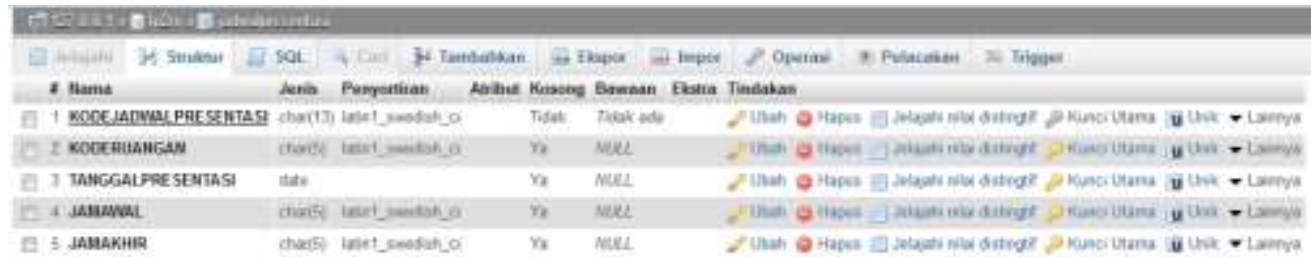

Gambar 38. Implementasi tabel Jadwal Presentasi

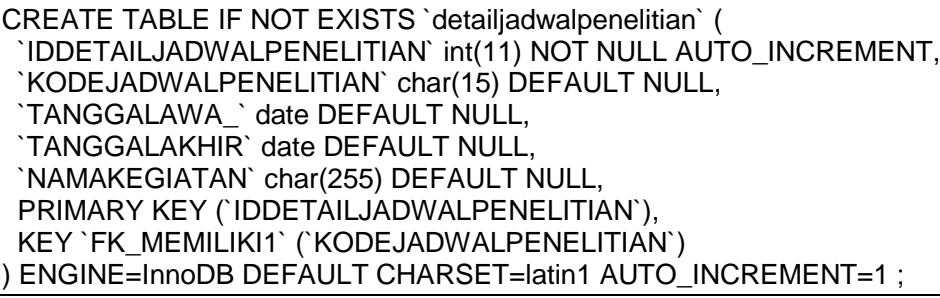

Gambar 39. Script Pembuatan Tabel Detail Jadwal Presentasi

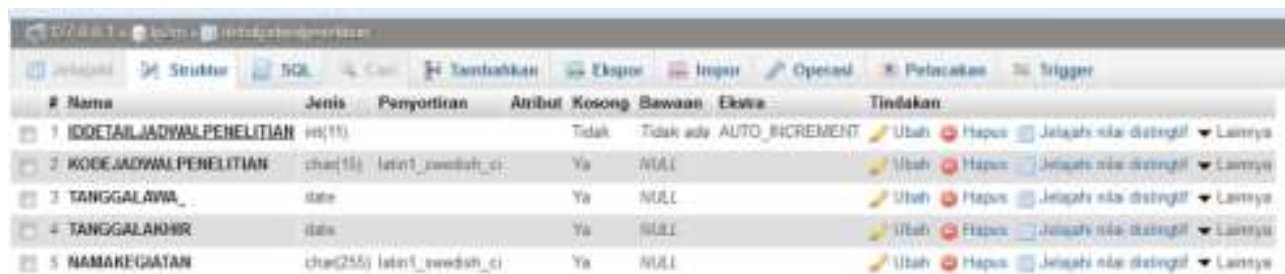

Gambar 40. Implementasi tabel Detail Jadwal Presentasi

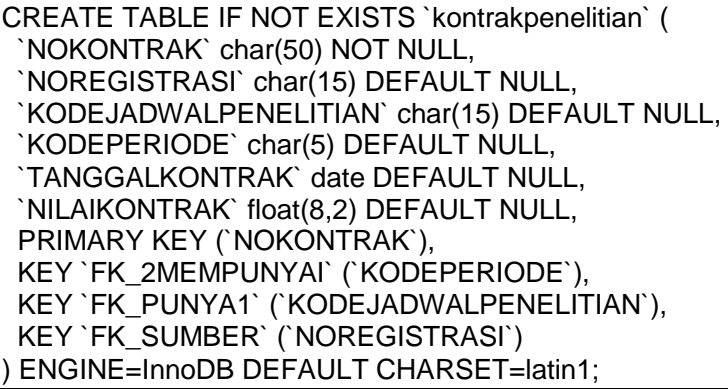

Gambar 41. Script Pembuatan Tabel Kontrak Penelitian 


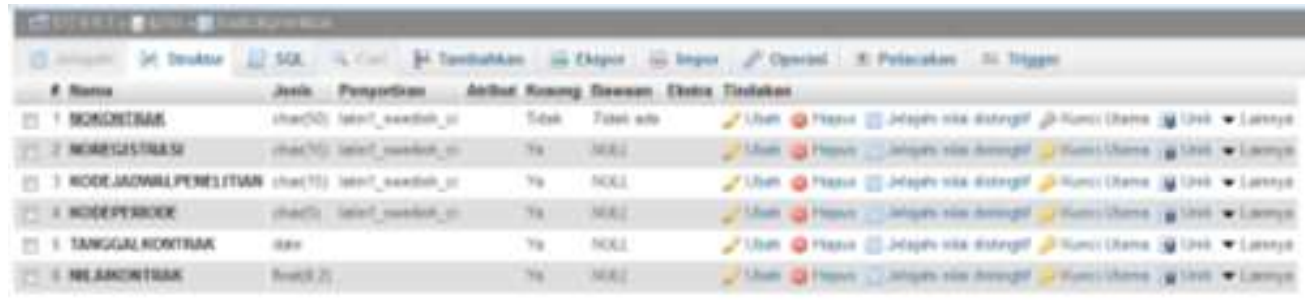

Gambar 42. Implementasi tabel Kontrak Penelitian

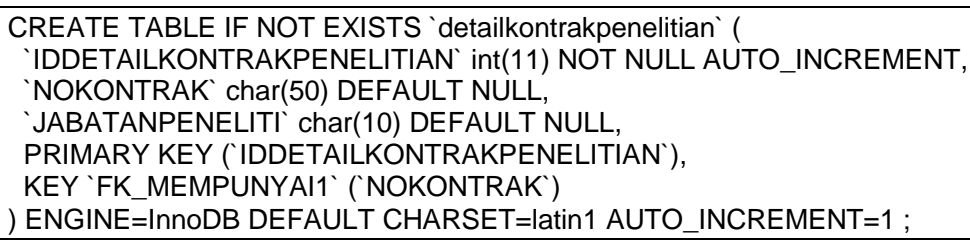

Gambar 43. Script Pembuatan Tabel Detail Kontrak Penelitian
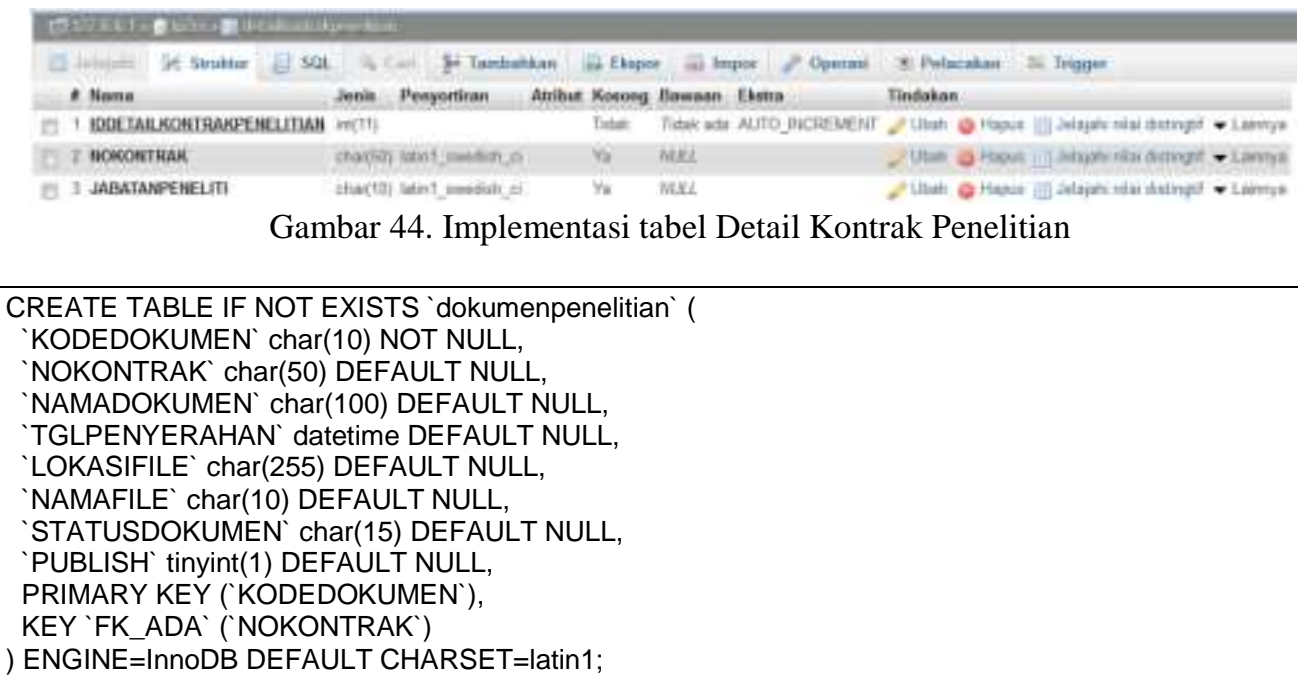

Gambar 45. Script Pembuatan Tabel Dokumen Penelitian

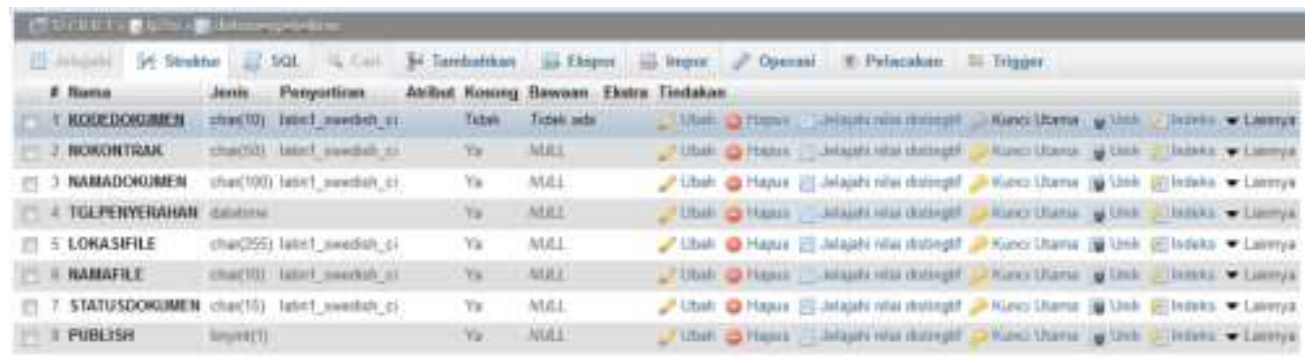

Gambar 46. Implementasi tabel Dokumen Penelitian 


\subsection{Implementasi Contrains}

Berikut ini script SQL yang untuk pembuatan constrain

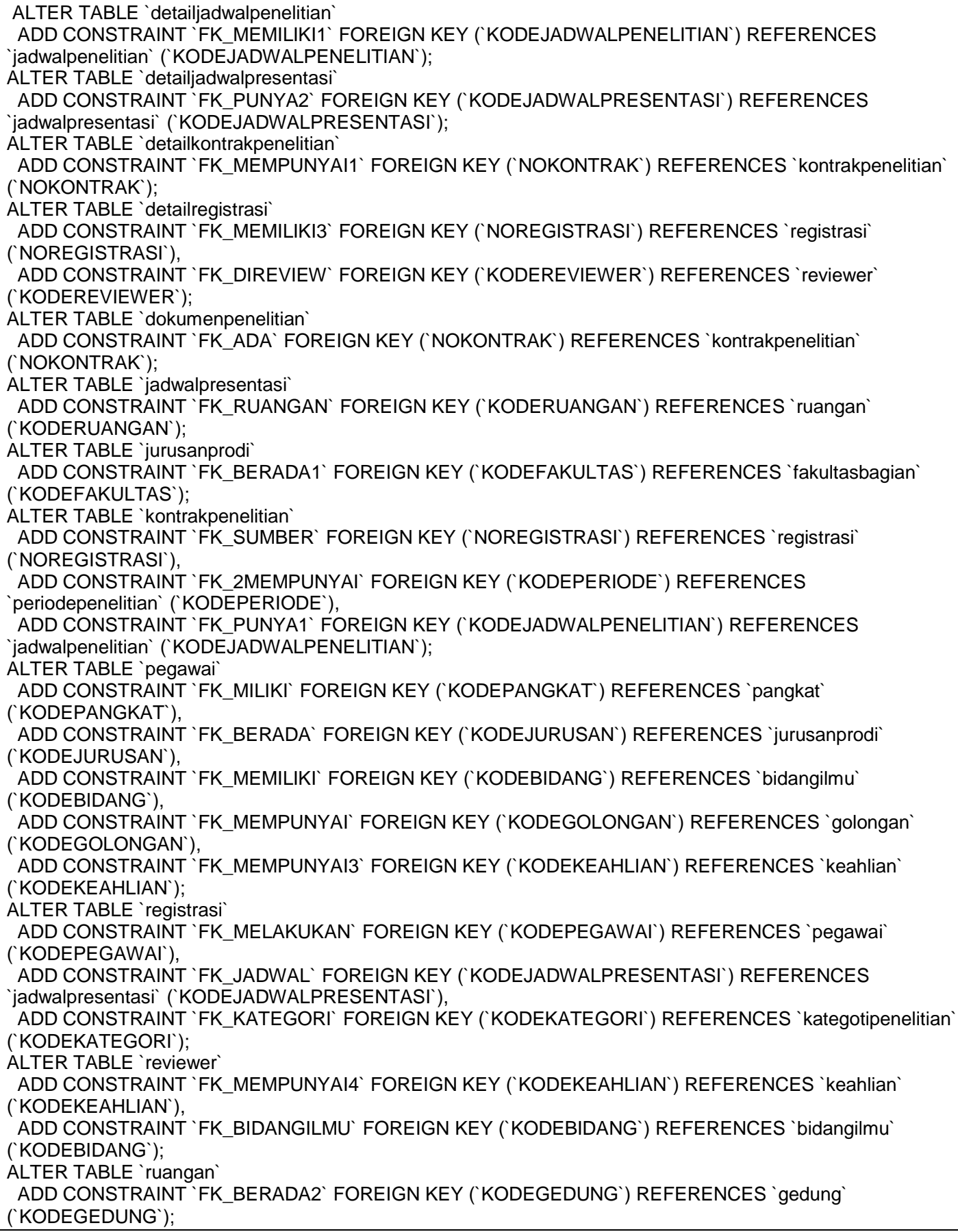

Gambar 47. Implementasi Constrain 


\section{Hasil}

Hasil dari analisis dan perancangan diperoleh basis data $1 \mathrm{p} 2 \mathrm{~m}$ dengan tabel-tabel sebagai berikut; detail jadwal penelitian, jadwal penelitian, detail jadwal presentasi, jadwal presentasi, detail kontrak penelitian, kontrak penelitian, detail registrasi, registrasi, reviewer, dokumen penelitian, ruangan, jurusan prodi, fakultas bagian, periode penelitian, pegawai, pangkat, bidang ilmu, golongan, keahlian, kategori penelitian, gedung.

\section{Kesimpulan}

Makalah ini merupakan makalah yang menjelaskan tentang analisis dan perancangan serta implementasi dari pengolahan data penelitian lp2m di lingkungan UIN Sunan Gunung Djati Bandung tahun 2016. Permasalahan yang ingin diselesaikan adalah penyimpanan data-data penelitian masih dilakukan di berbagai media penyimpanan dan dilakukan secara manual. Kontribusi dari penelitian ini adalah bahwa penelitian ini menghasilkan suatu rancangan basis data penelitian $1 \mathrm{p} 2 \mathrm{~m}$. Batasan dari penelitian ini adalah bahwa hasil rancangan belum dilakukan pengujian secara integrasi dengan aplikasi yang mengakses basis data secara langsung. Hasil menunjukan basis data dan tabel-tabel yang dihasilkan selama proses perancangan. Penelitian di masa datang adalah melakukan penelitian tentang integrasi aplikasi penelitian dengan basis data $\operatorname{lp} 2 \mathrm{~m}$.

\section{Ucapan Terima Kasih}

Penelitian ini didanai oleh dari DIPA-BOPTN UIN Sunan Gunung Djati Bandung Tahun Anggaran 2016, sesuai dengan Kontrak No: B-200/B1-69/V.2/PP.00.9/06/2016.

\section{Daftar Pustaka}

[1] T. C. a. C. Begg, A Practical Approach to Design, Implementation, and Management, 6th Edition, Glasgow: Pearson Education Limited, 2015.

[2] Fathansyah, Basis Data, Bandung: Informatika, 2012.

[3] C. Date, An Introduction to Database System, 8th Edition, 2000.

[4] "Visi, Misi, Tujuan dan Sasaran," LP2M UIN SGD Bandung, 2016. [Online]. Available: https://lp2m.uinsgd.ac.id/profil/visi-misi-dan-tujuan-lppm-uin-bandung.html. [Diakses 20 Agustus 2016].

[5] B. Nugroho, Database Relasional dengan MySQL., Yogyakarta: Penerbit Andi, 2013.

[6] H. F. K. a. S. S. Avi Silberschatz, Database System Concept, 5th Edition, 2006.

[7] Waliyanto, Sistem Basis Data Analisis dan Pemodelan Data, Yogyakarta: J \& J Learning, 2000.

[8] A. Nugroho, Perancangan \& Implementasi Sistem Basis Data, Yogyakarta: Andi Publisher, 2014.

[9] R. Yanto, Manajemen Basis Data Menggunakan MySQL, Yogyakarta: Deepublish, 2016.

[10] Kusrini, Strategi Perancangan dan Pengelolaan Basis Data, Yogyakarta: Andi Publisher, 2015. 